\title{
Grand challenges in pediatric otolaryngology
}

\author{
James M. Coticchia ${ }^{1}{ }^{*}$, David Cohen ${ }^{2}$ and Livjot Sachdeva' \\ 1 Division of Pediatric Otolaryngology, Department of Otolaryngology - Head and Neck Surgery, School of Medicine, Wayne State University, Detroit, MI, USA \\ 2 Department of Otolaryngology - Head and Neck Surgery, School of Medicine, Wayne State University, Detroit, MI, USA \\ *Correspondence: jcoticch@med.wayne.edu
}

Edited by:

Antonio Francesco Corno, King Fahad Medical City, Saudi Arabia

\section{INTRODUCTION}

The field of pediatric otolaryngology has undergone significant changes over the past two decades. These changes have resulted in new areas of investigations and challenges. This article will summarize some of the more recent advances and challenges facing this field. Specific focus of this grand challenge will include: (1) Role of biofilms in infectious diseases in otolaryngology, (2) tissue engineering in pediatric airway reconstructive surgery, (3) minimally invasive surgical techniques, and (4) advances in molecular biology of sensorineural hearing loss (SNHL).

\section{BIOFILMS AS UNIQUE MODEL FOR CHRONIC AND RECURRENT INFECTIONS IN OTOLARYNGOLOGY}

The burden of infectious diseases in several clinical problems encountered in pediatric otolaryngology is quite extensive. Though previously not well defined, the evidence to support biofilms as a pathophysiologic model in otolaryngology has increased remarkably over the last decade. Biofilms have been implicated in the pathogenesis of otitis media (OM), chronic rhinosinusitis (CRS), chronic tonsillitis, cholesteatoma, recurrent tracheitis, and cochlear implant infections.

The initial implication of biofilm phenotypes in acute $\mathrm{OM}(\mathrm{AOM})$ and $\mathrm{OM}$ with effusion (OME) was postulated following the observation fact that many patients with middle ear effusion were culture negative. Furthermore, several studies demonstrated that a significant portion of these effusions did in fact have bacterial mRNA or were PCR positive for bacterial DNA (1). These observations were paramount and suggested that biofilms may play a role in OM. Further research demonstrated that the three predominant causative agents for OM, Streptococcus pneumoniae, Haemophilus influenzae, and Moraxella catarrhalis, form biofilms in both in vitro and in vivo settings (2). This evidence, along with several investigations, would suggest that the primary pathogens for OM are capable of forming biofilms $(2,3)$. This is an important observation as bacteria in biofilm phenotypes can survive at antibiotic concentrations $>2000$ times the minimum inhibitory concentration (MIC) $(4,5)$.

The clinical importance of biofilm formation by known middle ear pathogens (MEPs) was also demonstrated by an animal model that closely parallels the human disease state. The model utilized superinfection of Influenza A and S. pneumoniae inoculation via the nasopharynx. Approximately $37 \%$ of these animals developed AOM and scanning electron microscopy (SEM) imaging identified robust biofilms in the nasopharynx, eustachian tube, and ME mucosa of these infected animals (6).

In regard to CRS, the chronic and medically refractive nature of the disease lends itself naturally to a biofilm model. Both human and rabbit models of sinusitis have repeatedly demonstrated the capability of infectious agents to form biofilms. In a critical study, Ramadan et al. analyzed tissue samples from patients with CRS under SEM and successfully showed that every sample had biofilms present in various phases of proliferation (7). Further studies confirmed that the three most common causative bacterial agents readily formed biofilms in respiratory epithelium of patients with CRS.

\section{FUTURE CHALLENGES}

- Development of non-invasive imaging techniques like optical coherence tomography and high frequency ultrasound to identify biofilms inside the human body $(8,9)$.

- Characterizing the role of host surface receptors in allowing initial attachment of biofilm forming pathogens.
- Defining the role of viral co-infection in altering respiratory epithelial surface to allow attachment and development of biofilms.

- Studying the role of host immune response to the formation of biofilms.

- Elucidating the environmental factors that favor development and/or degradation of biofilms. Recent studies have alluded to certain EPS lyases that are produced in response to specific environmental triggers such as oxygen depletion and can enzymatically degrade the EPS matrix releasing the cells from the biofilm (10).

\section{AIRWAY RECONSTRUCTION UTILIZING TISSUE ENGINEERING TECHNIOUES}

Tissue engineering is an interdisciplinary field where engineering and life science intersect with the hope of creating a biological substitute for human organs and tissues. Although airway reconstructive surgery arose in the late twentieth century, the rapid development and complexity of bioengineering and tissue regeneration has significantly shaped the current approach to airway reconstruction today.

Surgical management of long-segment tracheal stenosis in children by its very nature is very complex and challenging and has been evolving over the last two decades with patch (graft) tracheoplasty and slide tracheoplasty as the most common surgical techniques. Although the tissue grafts employed in patch tracheoplasty re-epithelialize rapidly, the eventual outcome of the surgery can be complicated by restenosis arising from granulation or shrinkage of the graft thus requiring reintervention. However, the experience with this technique has been reported in literature with varying degrees of success $(11,12)$. Fanous et al. reported successful long term outcomes for pericardial tracheoplasty performed on 26 patients with long- 
segment tracheal stenosis with five hospital deaths, none from airway obstruction, and two re-interventions (13). More recently, slide tracheoplasty with cardiopulmonary bypass support has shown encouraging short-term outcomes with early extubation post-op and shorter hospital stays for patients. Several authors have reported successful outcomes for long-segment stenosis using this technique with lower mortality rates ranging from 10 to $30 \%$, fewer postop complications and re-interventions as compared to other techniques (14-21). As with patch tracheoplasty, varying degrees of success have been reported with slide tracheoplasty with Manning et al. demonstrating lower rates of complications contrasting with the less encouraging experience of Wright et al. $(22,23)$.

Owing to the complexity of airway surgical management in children and varying degrees of successes with the current surgical techniques, the quest for the development of a novel allograft or biological implant for airway reconstruction is only logical. There are several limitations to creating novel implants in the airway reconstructive setting. These include life-threatening complications, small sample sizes, and a lack of human subjects due to the precarious nature of airway surgery. Such complications, including migration, dislodgement, infection, obstruction, adjacent site stenosis or granulation, and necrosis, have the potential for significant host morbidity and/ or mortality. In this way, the development of such an implant has been exceedingly difficult. For this reason, no clinically convincing tracheal replacement method or implant currently exists.

Belsey described the theoretical tracheal implant in the 1950s as a laterally rigid but longitudinally flexible, biocompatible, non-immunogenic, bacterial resistant, airtight stent that promotes respiratory epithelialization (24). Early scientists were thus disillusioned when they believed the implant to be as simple as developing a tubular cartilaginous structure. Later, animal models confirmed the importance of respiratory epithelialization in preventing granulomatous tissue formation and promoting cilia formation for functionality (25). Initial research efforts were largely tissue scaffolds aimed at guiding innate tissues for quicker regeneration. Shimizu and his colleagues were the first to use a synthetic scaffold consisting of Marlex mesh tube covered in a collagen sponge made from porcine dermal collagen as a tracheal implant, which was unsuccessful (26). The major limitation of acellular scaffolding implants is the potential for incomplete re-epithelialization, which may lead to biofilm formation, granulation tissue growth, or airway stenosis from cicatricial scar formation (27). Similarly, an animal study by Weidenbacher et al. demonstrated that when using a neo-tracheal tubular implant, all animals eventually developed cicatricial scar formation and had to be sacrificed (28). Therefore, the importance of epithelialization was confirmed, and research shifted toward tissue-engineered implants.

Tissue engineering involves the implantation of stem-cells onto bioscaffolding matrices. In these tissue models, functionality and epithelialization are aided through the use of stem-cells, which are believed to hasten the successful incorporation of such implants. While some studies have demonstrated the capability to seed mesenchymal stem-cells onto bioscaffolds to produce viable cardiac myocyte regeneration, the harvest and proliferation of human respiratory epithelial cells has proved more challenging (29). Currently, there is still no widely accepted seeding method for these cells (25). In addition to lacking a reliable source for respiratory stem-cells, further challenge rests in the structure of the human trachea itself. Between the epithelial and cartilaginous layers is a submucosal layer that is filled with a dense capillary network (30). Some scientists, such as Tan et al., hypothesize that it is the incapability of the implant to simulate this permeable quality that leads to such poor rates of successful allograft implantation. Others argue that epithelialization of the implant is key to successful implantation. Likely, it is a combination of these factors, as well as additional factors that have not been uncovered, which would ultimately lead to improved tissue-engineered tracheal implantation. In this way, the tissue-engineered trachea is still far away from clinical application. However, it remains a topic of interest due to its vast potential if such an implant is able to be designed.

\section{FUTURE CHALLENGES}

- Tissue-engineered construct for laryngotracheal reconstruction
- Tissue-engineered construct for longsegment tracheal stenosis

- Utility of augmented cadaveric fragment in tracheal reconstruction

\section{MINIMALLY INVASIVE TECHNIQUES AND ROBOTIC SURGERY}

Numerous fields have begun to embrace minimally invasive surgical approaches. These include laparoscopic surgery, endoscopic surgery approach for neurosurgical procedures, endoscopic management of mediastinal lesions to name a few. The advantages of minimally invasive procedures include decreased cosmetic scars, less dissection, and decreased morbidity. In addition to endoscopic procedures, robotic procedures offer many of the same advantages (31). Some recent areas of investigation include robotic assisted airway surgery, endoscopic airway surgery, endoscopic and robotic assisted thyroid surgery, and the potential for sentinel lymph nodes biopsy (32). Current applications in pediatric otolaryngology include endoscopic approach for juvenile nasal angiofibromas and endoscopic approaches for skull base tumors in children (33). In addition, other areas of investigation include robotic assisted tympanomastoid surgery and image guidance endoscopic management of congenital problems including choanal atresia and canal atresia.

\section{FUTURE CHALLENGES}

- Develop smaller instruments and novel approaches for endoscopic robotic assisted airway surgery

- Develop novel techniques for endoscopic neck biopsies and management of congenital neck mass

- Develop a wider array of instruments and novel approaches for image guided endoscopic choanal atresia surgery

- Utilize robotic approach and image guidance for pediatric mastoid surgery and cochlear implant surgery

\section{MOLECULAR BIOLOGY OF AUDITORY REGENERATION IN SNHL}

Loss of inner ear (IE) functionality and balance disorders due to hair cell damage can occur through ototoxic, acoustic, environmental, or chemical damage as well as aging or genetic conditions. Restoration of IE functionality through hair cell regeneration was not even considered a possibility until the discovery of hair cell regeneration in 
avian IE. While non-mammals mount an active regenerative response to hair cell damage via proliferation and differentiation of supporting cells, auditory regeneration in mammalian IE is not as pronounced since most supporting cells maintain mitotic quiescence. However, investigations to study the role of protein regulation, growth factors, and molecular signaling pathways in the regenerative response in non-mammals have opened a plethora of opportunities to manipulate and study the response in mammals.

Several key regulators have been identified in non-mammals that can stimulate or inhibit proliferation of supporting cells. Insulin-like growth factor 1 (IGF-1) has been shown to be upregulated in avian vestibular epithelium post hair cell damage while fibroblast growth factor 2 (FGF-2) has been shown to inhibit cell proliferation (34, 35). Expression of actin-interacting protein WD40 and fibroblast growth factor receptor 3 (FGFR3) has been shown to be upregulated in the supporting cells in non-mammals that exhibit hair cell regeneration $(36,37)$. Studies by Bermingham et al. (1999) have demonstrated the role of basic helix-loop-helix transcription factor like mammalian atonal homolog 1 (Math1) in promoting the differentiation of supporting cells into hair cells (38). However, in vivo studies by several investigators to manipulate the expression of Math1 in the organ of Corti in mammals have revealed mixed evidence with respect to regenerative response and functional recovery (39-43).

\section{FUTURE CHALLENGES}

- Gene expression profiling to study regulation of cell proliferation in auditory and vestibular sensory epithelia

- Targeted gene delivery and expression and potential gene therapy using adenovirus technology [44)

- Using stem cell technology to induce cells to proliferate and differentiate into hair cells [45)

\section{CONCLUSION}

Pediatric otolaryngology was born out of a need for specialists to treat and manage congenital complications in infants and children. Since its inception, this field has made rapid advances with innovative technological breakthroughs, scientific discoveries, and therapeutic interventions - some of which have been briefly discussed in this article. However, as outlined above, there are some great challenges ahead of us and it's imperative that we ride on our recent success and look to extend the current boundaries. With science and medicine becoming more and more interdisciplinary, we are poised to make rapid advances and are placed in an excellent position to overcome current challenges and discover new ones.

\section{REFERENCES}

1. Bakaletz LO. Bacterial biofilms in otitis media: evidence and relevance. Pediatr Infect Dis J (2007) 26(Suppl 10): S17-9.

2. Ehrlich GD, Veeh R, Wang X, Costerton JW, Hayes JD, Hu FZ, et al. Mucosal biofilm formation on middle-ear mucosa in the chinchilla model of otitis media. JAMA (2002) 287(13):1710-5.

3. Hall-Stoodley L, Hu FZ, Gieseke A, Nistico L, Nguyen D, Hayes J, et al. Direct detection of bacterial biofilms on the middle-ear mucosa of children with chronic otitis media. JAMA (2006) 296(2):202-11.

4. Anderl JN, Franklin MJ, Stewart PS. Role of antibiotic penetration limitation in Klebsiella pneumoniae biofilm resistance to ampicillin and ciprofloxacin. Antimicrob Agents Chemother (2000) 44(7):1818-24.

5. Stewart PS, Costerton JW. Antibiotic resistance of bacteria in biofilms. Lancet (2001) 358(9276):135-8.

6. Hoa M, Syamal M, Sachdeva L, Berk R, Coticchia J. Demonstration of nasopharyngeal and middle ear mucosal biofilms in an animal model of acute otitis media. Ann Otol Rhinol Laryngol (2009) 118(4):292-8.

7. Ramadan HH, Sanclement JA, Thomas JG. Chronic rhinosinusitis and biofilms. Otolaryngol Head Neck Surg (2005) 132(3):414-7.

8. Nguyen CT, Jung W, Kim J, Chaney EJ, Novak M, Stewart CN, et al. Noninvasive in vivo optical detection of biofilm in the human middle ear. Proc Natl Acad Sci U S A (2012) 109(24):9529-34.

9. Vaidya K. High frequency ultrasound imaging and characterization of biofilms. IEEE International Ultrasonics Symposium; 2011, Orlando. (2011). $1395 \mathrm{p}$.

10. Allison DG, Ruiz B, SanJose C, Jaspe A, Gilbert P. Extracellular products as mediators of the formation and detachment of Pseudomonas fluorescens biofilms. FEMS Microbiol Lett (1998) 167(2):179-84.

11. Valencia D, Overman D, Tibesar R, Lander T, Moga F, Sidman J. Surgical management of distal tracheal stenosis in children. Laryngoscope (2011) 121(12):2665-71. doi: 10.1002/lary.22355.

12. Yang JH, Jun TG, Sung K, Choi JH, Lee YT, Park PW. Repair of long-segment congenital tracheal stenosis. J Korean Med Sci (2007) 22(3):491-6.

13. Fanous N, Husain SA, Ruzmetov M, Rodefeld MD, Turrentine MW, Brown JW. Anterior pericardial tracheoplasty for long-segment tracheal stenosis: long-term outcomes. J Thorac Cardiovasc Surg (2010) 139(1):18-23; discussion 23-5. doi: 10.1016/j.jtcvs.2009.09.040. Epub 2009 Nov 11.

14. Matúte JA, Romero R, Garcia-Casillas MA, de Agustìn JC, Marhuenda C, Berchi FJ, et al. Surgical approach to funnel-shaped congenital tracheal stenosis. J Pediatr Surg (2001) 36(2):320-3.

15. Elliott M, Roebuck D, Noctor C, McLaren C, Hartley $\mathrm{B}, \mathrm{Mok} \mathrm{Q}$, et al. The management of congenital tracheal stenosis. Int J Pediatr Otorhinolaryngol (2003) 67(Suppl 1):S183-92.

16. Chiu PP, Kim PC. Prognostic factors in the surgical treatment of congenital tracheal stenosis: a multicenter analysis of the literature. JPediatr Surg (2006) 41(1):221-5; discussion 221-5.

17. Forsen JW Jr., Lusk RP, Huddleston CB. Costal cartilage tracheoplasty for congenital long-segment tracheal stenosis. Arch Otolaryngol Head Neck Surg (2002) 128(10):1165-71.

18. Herrera P, Caldarone C, Forte V, Campisi P, Holtby $\mathrm{H}$, Chait $\mathrm{P}$, et al. The current state of congenital tracheal stenosis. Pediatr Surg Int (2007) 23(11):103344. Epub 2007 Aug 22. Review.

19. Kocyildirim E, Kanani M, Roebuck D, Wallis C, McLaren C, Noctor C, et al. Long-segment tracheal stenosis: slide tracheoplasty and a multidisciplinary approach improve outcomes and reduce costs. $J$ Thorac Cardiovasc Surg (2004) 128(6):876-82.

20. Tsugawa C, Nishijima E, Muraji T, Satoh S, Takamizawa S, Yamaguchi M, et al. Tracheoplasty for long segment congenital tracheal stenosis: analysis of 29 patients over two decades. J Pediatr Surg (2003) 38(12):1703-6.

21. Li X, Cheng LC, Cheung YF, Lun KS, Chau KT, Chiu SW. Management of symptomatic congenital tracheal stenosis in neonates and infants by slide tracheoplasty: a 7-year single institution experience. Eur J Cardiothorac Surg (2010) 38(5):609-614. doi: 10.1016/j.ejcts.2010.03.011. Epub 2010 Apr 22.

22. Manning PB, Rutter MJ, Lisec A, Gupta R, Marino BS. One slide fits all: the versatility of slide tracheoplasty with cardiopulmonary bypass support for airway reconstruction in children. J Thorac Cardiovasc Surg (2011). 141(1):155-61. doi: 10.1016/j.jtcvs.2010.08.060. Epub 2010 Nov 5.

23. Wright CD, Graham BB, Grillo HC, Wain JC, Mathisen DJ. Pediatric tracheal surgery. Ann Thorac Surg (2002) 74(2):308-13; discussion 314.

24. Belsey R. Resection and reconstruction of the intrathoracic trachea. Br J Surg (1950) 38(150):200-5.

25. Tan Q, Steiner R, Hoerstrup SP, Weder W. Tissueengineered trachea: history, problems and the future. Eur J Cardiothorac Surg (2006) 30(5):782786. Epub 2006 Oct 2. Review.

26. Okumura N, Teramachi M, Takimoto Y, Nakamura T, Ikada Y, Shimizu Y. Experimental reconstruction of the intrathoracic trachea using a new prosthesis made from collagen grafted mesh. ASAIO J (1994) 40(3):M834-9.

27. Walles T. Tracheobronchial bio-engineering: biotechnology fulfilling unmet medical needs. Adv Drug Deliv Rev (2011) 63(4-5):367-74. doi: 10.1016/j. addr.2011.01.011. Epub 2011 Feb 2. Review.

28. Weidenbecher M, Tucker HM, Gilpin DA, Dennis JE. Tissue-engineered trachea for airway reconstruction. Laryngoscope (2009) 119(11):2118-23.

29. Potapova IA, Doronin SV, Kelly DJ, Rosen AB, Schuldt AJ, Lu Z, et al. Enhanced recovery of mechanical function in the canine heart by seeding an extracellular matrix patch with mesenchymal stem cells committed to a cardiac lineage. Am J Physiol Heart Circ Physiol (2008) 295(6):H2257-63. Epub 2008 Oct 3. 
30. Staudenmaier R, Hoang TN, Kleinsasser N, Schurr C, Frolich K, Wenzel MM, et al. Flap prefabrication and prelamination with tissue-engineered cartilage. J Reconstr Microsurg (2004) 20:555-64.

31. Rahbar R, Ferrari LR, Borer JG, Peters CA. Robotic surgery in the pediatric airway: application and safety. Arch Otolaryngol Head Neck Surg (2007) 133(1):46-50.

32. Durel J, Kluka E, Walvekar RR. Minimally invasive video-assisted thyroidectomy for treatment of benign solitary thyroid nodules in pediatric patients. Ochsner J (2011) 11(2):128-31.

33. Benoit MM, Silvera VM, Nichollas R, Jones D, McGill T, Rahbar R. Image guidance systems for minimally invasive sinus and skull base surgery in children. Int J Pediatr Otorhinolaryngol (2009) 73(10):1452-7. doi: 10.1016/j.ijporl.2009.07.017. Epub 2009 Aug 19.

34. Oesterle EC, Tsue TT, Rubel EW. Induction of cell proliferation in avian inner ear sensory epithelia by insulin-like growth factor-I and insulin. J Comp Neurol (1997) 380(2):262-74.

35. Oesterle EC, Bhave SA, Coltrera MD. Basic fibroblast growth factor inhibits cell proliferation in cultured avian inner ear sensory epithelia. J Comp Neurol (2000) 424(2):307-26.

36. Bermingham-McDonogh O, Stone JS, Reh TA, Rubel EW. FGFR3 expression during development and regeneration of the chick inner ear sensory epithelia. Dev Biol (2001) 238(2):247-59.

37. Pirvola U, Cao Y, Oellig C, Suoqiang Z, Pettersson RF, Ylikoski J. The site of action of neuronal acidic fibroblast growth factor is the organ of Corti of the rat cochlea. Proc Natl Acad Sci U S A (1995) 92(20):9269-73.

38. Bermingham NA, Hassan BA, Price SD, Vollrath MA, Ben-Arie N, Eatock RA, et al. Math1: an essential gene for the generation of inner ear hair cells. Science (1999) 284(5421):1837-41.

39. Kawamoto K, Ishimoto S, Minoda R, Brough DE, Raphael Y. Math1 gene transfer generates new cochlear hair cells in mature guinea pigs in vivo. $J$ Neurosci (2003) 23(11):4395-400.

40. Izumikawa M, Minoda R, Kawamoto K, Abrashkin KA, Swiderski DL, Dolan DF, et al. Auditory hair cell replacement and hearing improvement by Atohl gene therapy in deaf mammals. Nat Med (2005) 11(3):271-6. Epub 2005 Feb 13.

41. Staecker H, Praetorius M, Baker K, Brough DE Vestibular hair cell regeneration and restoration of balance function induced by mathl gene transfer. Otol Neurotol (2007) 28(2):223-31.

42. Schlecker C, Praetorius M, Brough DE, Presler RG Jr., Hsu C, Plinkert PK, et al. Selective atonal gene delivery improves balance function in a mouse model of vestibular disease. Gene Ther (2011) 18(9):884-90. doi: 10.1038/gt.2011.33. Epub 2011 Apr 7.
43. Liu Z, Dearman JA, Cox BC, Walters BJ, Zhang L Ayrault $\mathrm{O}$, et al. Age-dependent in vivo conversion of mouse cochlear pillar and Deiters' cells to immature hair cells by Atoh1 ectopic expression. J Neurosci (2012) 32(19):6600-10. doi: 10.1523/ jneurosci.0818-12.2012.

44. Fukui H, Raphael Y. Gene therapy for the inner ear. Hear Res (2013) 297:99-105. doi: 10.1016/j. heares.2012.11.017. Epub 2012 Dec 21.

45. Okano T, Kelley MW. Stem cell therapy for the inner ear: recent advances and future directions. Trends Amplif (2012) 16(1):4-18. doi: 10.1177/1084713812440336. Epub 2012 Apr 17.

Received: 02 April 2013; accepted: 01 May 2013; published online: 20 May 2013.

Citation: Coticchia JM, Cohen D and Sachdeva L (2013) Grand challenges in pediatric otolaryngology. Front Pediatr. 1:10. doi: 10.3389/fped.2013.00010

This article was submitted to Frontiers in Pediatric Otolaryngology, a specialty of Frontiers in Pediatrics. Copyright $(2013$ Coticchia, Cohen and Sachdeva. This is an open-access article distributed under the terms of the Creative Commons Attribution License, which permits use, distribution and reproduction in other forums, provided the original authors and source are credited and subject to any copyright notices concerning any thirdparty graphics etc. 